doi.org/10.46291/ISPECIJSSHvol4iss2pp111-128

\title{
THE PREVALENCE OF PERFORMANCE-RELATED PAY: A 23-COUNTRY EXAMINATION
}

\author{
Fulya AYDINLI KULAK \\ Assoc. Prof. Dr., Department of Human Resource Management, School of Business, Istanbul \\ University, Istanbul, Turkey, fulyaa@istanbul.edu.tr \\ ORCID: 0000-0002-5487-6345
}

\begin{abstract}
Sevgi ELMAS ATAY ${ }^{1}$
Res. Assist. (PhD), Department of Human Resource Management, School of Business, Istanbul University, Istanbul, Turkey, sevgielmas@istanbul.edu.tr
\end{abstract}

ORCID: 0000-0002-2238-4979

\begin{abstract}
This study intends to determine the current situation regarding the prevalence of pay for performance systems established for managers. Examining performance-related pay, we focus on individual, team and organizational performance and explore how widespread several pay components are in 23 countries. The research consists of the firm-level data of 5217 large companies from 23 countries from the Cranfield Network on Comparative Human Resource Management database. The data has been presented descriptively via frequencies and percentages and then analyzed via cluster analysis. In this way, diverging country clusters have been determined regarding the prevalence of pay for performance. Findings show that individual bonus is the most frequently used variable pay component provided to managers in general. Following that, paying for organizational performance is highly prevalent, whereas team-based bonuses are rarely used as a whole. On the other hand, long term incentives are rarely used except profit sharing. The results are descriptive in nature. This study addresses how widespread performance-related pay in various countries. Evidence regarding the use and prevalence of pay for performance systems across countries is quite limited. So this research, reflecting the current scene regarding variable pay in various countries, contributes to current literature by presenting recent comparable data.
\end{abstract}

Keywords: Compensation management, Pay for performance, International comparisons, Cluster analysis, Cranet survey

1 Corresponding author

Year 4/ 2020, Volume-4, Issue-2 | www.ispecjournal.org 


\section{INTRODUCTION}

Considering the main objective of Human Resource Management function is to increase productivity (Bloom and Van Reenan, 2011; Dessler, 2016; Sadullah, 2018), compensation management has a crucial role in enhancing performance and motivation thus in increasing productivity (Adeoye and Elegunde, 2014; DeCenzo et al. 2013; Noe et al. 2017). Empirical research shows that specifically performancerelated pay helps companies accomplish the objective of productivity enhancement (Booth and Frank, 1999; Gielen et al. 2010). Compensation theories (e.g., reinforcement, expectancy, agency theories) also argue that incentives and reinforcement are priority elements of workplace behaviors such as employees' productivity, employee attraction and retention (Gerhart and Fang, 2014). Pay for performance systems, as a crucial tool to enhance motivation and performance, seem to present an increasing trend since 1980's (Bryson et al. 2012: 1). This research aims to determine the current prevalence of pay for performance in various countries.

\section{LITERATURE REVIEW}

In pay for performance systems, the emphasis may be on outcomes (such as sales and profits etc.) or behaviors (e.g., supervisor ratings of behaviors). Performance can be measured at the individual employee level or assembled (e.g. team or organization) level (Gerhart and Fang, 2014). So pay for performance systems can be based on team and/or organizational performance as well as individual performance (Durham and Bartol, 2000).

Considerable crucial meta-analyses of pay and productivity (e.g., Jenkins et al. 1998; Cerasoli et al. 2014) in the literature indicates that individual pay incentives meaningfully increase performance (Cadsby et al. 2007). In addition to this, teambased incentives are the best form to strengthen cooperation and are likely to boost employees' organizational citizenship behavior and enhance employees' capabilities, flexibility and productivity (Delfgaauw et al. 2018). When coordination is not required, team-based incentives are unlikely to be efficient and compensation policies are largely based on the observable outcomes. If powerful incentives are especially 
important but individual work is not observable, it is proper to use team-based compensation. Additionally, team-based pay may attract low-skilled and/or less productive employees than individual-based pay considering their lower earning potential (Larkin et al. 2012).

Organizational incentive programs, including their performance measurement process and decision-making policies, are generally effective in improving organizational goals and are necessary aspects in organizations operating (James, 2005). An arrangement which provides variable compensation according to performance during a period that extends above one year can be defined as "a long term incentive". This incentive can be categorized as cash or stock. These systems give managers with accumulation of capital opportunity with commonly favorable accounting, cash flow and tax for the company (Chingos, 2002).

Financial incentives such as profit sharing, employee share ownership and stock option plans are said to be becoming part of the employment relationship especially in the industrialized world (Poutsma et al. 2012: 1513). A profit-sharing plan can be defined "as a plan in which part of employee compensation during a particular period is based substantially on the profitability of the company in that period" (Kruse, 1993: 5). On the other hand, share in ownership is provided to employees and/or managers in employee share ownership plans. There are three main alternatives in providing shares to employees and/or managers. One of them is to provide direct purchase of sales opportunities. Secondly, they may be provided transfers financed by business profits. Finally, they may be provided opportunities to purchase shares at one point of time in the long run (Pendleton et al., 2001: 8-9). According to Pendleton et al. (2001), European average is $45 \%$ for profit-sharing and $31 \%$ for share ownership in 2000. There is also proof on prevalence and growth of profit-sharing between 1955 and 1991 in the USA. The prevalence has grown from $13 \%$ to $21 \%$ in this period (Kruse, 1993: 8). It is clear that we need more recent data to have a view regarding the current situation of long term incentives.

Another long term incentive focused in this study is stock options. Stock options give an employee the option with the right to asset a given shares of common stock at a 
stable price for a certain term, generally 10 years. The option exercise price, or strike price, is normally set equal to the market value of a share on the date of grant but may be set above fair market value ("premium-priced options") or below fair market value ("discounted options"). Today most firms use stock options priced "at the money" as their accumulation of capital plan (Chingos, 2002: 209). Stock-based incentives may encourage executives to hide negative news related with growth potentials or promote dishonest financial reporting. According to Carson (2003), managers are provided stock options as incentives and this will lead them have self-enrichment.

Stock options may cause decreasing motivation and performance than merit pay, due to their value is consistently carried out by market forces. This is to say that value of stock options is not only carried by the business' performance alone. The employees, individually, have only a limited effect on the financial situation of the organization. The unfavorable effect may be moderated by the perception of ownership/control provided to individuals. For the reason, not only monetary values are provided to managers in stock options, but non-monetary elements such as ownership perceptions are also ensured (Kraizberg et al. 2002).

There are several advantages and disadvantages of pay-for-performance systems as a whole. Gilbreath and Harris (2002) stated improved role clarity, increased sense of fairness on employees and increased motivation as an advantage of these plans. They also pointed out possible negative effects of a pay-for-performance plan, for instance decreased positive motivation for certain actions (e.g., cooperation with other employees), decrease in motivation (e.g., unethical behavior to accomplish the goals), deriving from a perception of being forced to be effective.

Along with pros and cons of pay for performance systems, companies provide variable pay components to their managers. According to the findings of the European Company Survey 2013, 62 \% of European companies use variable pay whatever the form is (Eurofound, 2016: 17). According to Bryson et al. (2012), 10 and $15 \%$ of the employees are provided incentive pay schemes ranges in several European countries. Besides, the prevalence of incentive pay schemes in Sweden, Norway, Denmark and the US goes beyond $40 \%$. 
In this study, we have sought to determine at what rate pay for performance systems are used in various countries currently. In this way first of all, we investigate the prevalence of pay for individual, team and organizational performance in 23 countries. Secondly, the prevalence of long term incentives such as profit-sharing, employee share schemes and stock options has been investigated. Moreover, 23 countries have been grouped according to the prevalence of those variable pay components and country clusters using these variable pay components highly, moderately and rarely have been identified. So this research enables us to see the current scene in pay for performance practices in various countries.

\section{RESEARCH}

\subsection{Research Method}

This research is based on extensive data of the Cranfield Network on International Human Resource Management (HRM) (Cranet) 2015-2016. The Cranet Network was founded in 1989 and has been conducting the largest survey of HRM practices around the world. Currently, universities and business schools in more than 40 countries represent their countries in the network. Cranet research includes large companies with more than 200 employees. The data has been collected through questionnaires. The most crucial goals of this network are to design an internationally comparative research and comparable database that would allow research into whether a pattern of "divergence" and "convergence" occur in HRM in different contexts (Brewster et al. 2011).

For the purpose of this study, only the variables related to executive pay practices have been used in the analyses. In the research, the variables related to executive pay practices of 5217 companies performing in 23 countries have been presented descriptively and then analyzed via cluster analysis. In this way, converging and diverging country clusters according to companies' variable pay practices have been obtained.

\subsection{Research Findings}

Year 4/ 2020, Volume-4, Issue-2 | WwW.ispecjournal.org 
First of all, the prevalence of performance-related pay in the 23 countries are presented in terms of performance dimensions used (individual, team and organizational performance).

It is clearly seen from Table 1 that paying for individual performance is the most preferred type of variable pay in most of the countries. Following individual performance, companies also pay for organizational performance. On the other hand, less companies pay for team performance in general. This general trend is for countries such as France, Italy, Germany, Switzerland and Austria etc. whereas the trend is just the opposite in China. This is to say, in China most of the companies (70 \%) pay for organizational performance, $63 \%$ of them pay for team performance and finally $57 \%$ of the companies pay for individual performance. Additionally, organizational bonuses are the most preferred variable pay component in the UK, Norway and Romania. Secondly individual bonuses and thirdly team bonuses are provided in those countries.

Table 1: Managerial Pay for Performance Based on Several Dimensions

\begin{tabular}{|c|c|c|c|c|c|c|}
\hline \multirow[t]{2}{*}{ Country } & \multicolumn{2}{|c|}{$\begin{array}{l}\text { Individual Goals } \\
\text { / Performance }\end{array}$} & \multicolumn{2}{|c|}{$\begin{array}{l}\text { Team Goals / } \\
\text { Performance }\end{array}$} & \multicolumn{2}{|c|}{$\begin{array}{l}\text { Organizational } \\
\text { Goals } \\
\text { Performance }\end{array}$} \\
\hline & $(\%)$ & $(\mathbf{f} / \mathbf{N})$ & $(\%)$ & $(\mathbf{f} / \mathbf{N})$ & $(\%)$ & $(\mathbf{f} / \mathbf{N})$ \\
\hline France & 91 & $\begin{array}{ll}136 \\
150\end{array}$ & 45 & $\begin{array}{ll}60 & / \\
133\end{array}$ & 62 & $\begin{array}{ll}91 & / \\
146\end{array}$ \\
\hline Italy & 81 & $\begin{array}{ll}136 \\
168\end{array}$ & 59 & $\begin{array}{ll}99 & / \\
168\end{array}$ & 75 & $\begin{array}{l}126 \\
168\end{array}$ \\
\hline UK & 79 & \begin{tabular}{|ll}
112 \\
142
\end{tabular} & 50 & $\begin{array}{ll}50 \\
101\end{array}$ & 83 & $\begin{array}{l}124 \\
149\end{array}$ \\
\hline Russia & 76 & $\begin{array}{|ll|}97 & / \\
127 & \end{array}$ & 54 & $\begin{array}{ll}68 & / \\
127\end{array}$ & 75 & $\begin{array}{ll}96 & / \\
128\end{array}$ \\
\hline Belgium & 73 & $\begin{array}{l}101 \\
138 \\
\end{array}$ & 52 & $\begin{array}{l}72 \\
138\end{array}$ & 73 & $\begin{array}{l}101 \\
138\end{array}$ \\
\hline Germany & 65 & $\begin{array}{l}180 \\
277 \\
\end{array}$ & 27 & $\begin{array}{ll}73 & / \\
269\end{array}$ & 52 & $\begin{array}{l}145 \\
277\end{array}$ \\
\hline Switzerland & 65 & $\begin{array}{|ll|}123 & / \\
189 & \\
\end{array}$ & 34 & $\begin{array}{ll}60 & / \\
178\end{array}$ & 61 & $\begin{array}{l}115 \\
189\end{array}$ \\
\hline Austria & 65 & $\begin{array}{ll}139 & / \\
214 & \\
\end{array}$ & 26 & $\begin{array}{ll}55 & / \\
214\end{array}$ & 44 & $\begin{array}{l}93 \\
213\end{array}$ \\
\hline Netherlands & 60 & $\begin{array}{ll}99 & / \\
165 & \end{array}$ & 30 & $\begin{array}{ll}49 \\
163\end{array}$ & 48 & $\begin{array}{ll}78 & \text { / } \\
163\end{array}$ \\
\hline Greece & 58 & $106 /$ & 40 & 72 & 37 & 48 \\
\hline
\end{tabular}

Year 4/ 2020, Volume-4, Issue-2 | www.ispecjournal.org 


\begin{tabular}{|c|c|c|c|c|c|c|c|}
\hline & & 183 & & 180 & & & 129 \\
\hline China & 57 & $\begin{array}{ll}146 & / \\
256\end{array}$ & 63 & $\begin{array}{l}160 \\
256\end{array}$ & $\pi$ & 70 & $\begin{array}{ll}178 \\
256\end{array}$ \\
\hline Denmark & 56 & $\begin{array}{ll}99 & / \\
178\end{array}$ & 26 & $\begin{array}{l}47 \\
178\end{array}$ & I & 47 & $\begin{array}{ll}83 & / \\
178\end{array}$ \\
\hline $\begin{array}{l}\text { South } \\
\text { Africa }\end{array}$ & 55 & $\begin{array}{ll}67 & / \\
121 & \end{array}$ & 26 & $\begin{array}{l}31 \\
121\end{array}$ & I & 41 & $\begin{array}{ll}50 \\
121\end{array}$ \\
\hline Croatia & 54 & $\begin{array}{ll}73 & / \\
136\end{array}$ & 32 & $\begin{array}{l}42 \\
130\end{array}$ & 1 & 49 & $\begin{array}{ll}68 & / \\
140 & \end{array}$ \\
\hline USA & 54 & $\begin{array}{ll}197 & / \\
362 & \\
\end{array}$ & 37 & $\begin{array}{l}133 \\
362 \\
\end{array}$ & / & 51 & $\begin{array}{ll}183 & 1 \\
362 & \\
\end{array}$ \\
\hline Turkey & 54 & $\begin{array}{ll}83 & / \\
154\end{array}$ & 40 & $\begin{array}{l}61 \\
154\end{array}$ & I & 33 & $\begin{array}{ll}50 \\
154\end{array}$ \\
\hline Australia & 47 & $\begin{array}{ll}185 & / \\
395\end{array}$ & 28 & $\begin{array}{l}112 \\
395\end{array}$ & / & 40 & $\begin{array}{ll}159 \\
395\end{array}$ \\
\hline Hungary & 47 & $\begin{array}{ll}129 & / \\
273 & \\
\end{array}$ & 28 & $\begin{array}{l}75 \\
273\end{array}$ & I & 41 & $\begin{array}{ll}113 & / \\
273 & \\
\end{array}$ \\
\hline Brazil & 44 & $\begin{array}{ll}156 \\
354\end{array}$ & 33 & $\begin{array}{l}115 \\
354\end{array}$ & I & 44 & $\begin{array}{ll}155 \\
354\end{array}$ \\
\hline Finland & 38 & $\begin{array}{ll}66 & / \\
172\end{array}$ & 18 & $\begin{array}{l}29 \\
163\end{array}$ & I & 37 & $\begin{array}{ll}65 & / \\
176\end{array}$ \\
\hline Norway & 37 & $\begin{array}{ll}61 & / \\
163\end{array}$ & 18 & $\begin{array}{l}29 \\
163 \\
\end{array}$ & 1 & 47 & $\begin{array}{ll}77 & \prime \\
163\end{array}$ \\
\hline Sweden & 31 & $\begin{array}{ll}82 & / \\
261 & \end{array}$ & 22 & $\begin{array}{l}56 \\
261\end{array}$ & I & 26 & $\begin{array}{l}69 \\
261\end{array}$ \\
\hline Romania & 22 & $\begin{array}{ll}50 & / \\
225 & \end{array}$ & 9 & $\begin{array}{l}21 \\
225\end{array}$ & 1 & 36 & $\begin{array}{ll}82 & 1 \\
225\end{array}$ \\
\hline
\end{tabular}

Noteworthy findings from Table 1 can be listed as follow:

- The companies in France scored highest for variable pay with $91 \%$ in individual bonuses.

- The companies in the UK scored highest for variable pay with $83 \%$ in organizational bonuses.

- The companies in China scored highest for variable pay with $63 \%$ in team bonuses.

- On the other hand, Romanian sample scored lowest both in individual (22\%) and team ( $9 \%)$ bonuses.

- The companies in Sweden also scored lowest in organizational bonuses with 26 $\%$. 
Most of the companies pay their managers for team performance in countries such as China (63\%), Italy (59 \%), Russia (54\%) and Belgium (52\%). Most of the companies pay their managers for organizational performance in the UK (83\%), Italy (75 \%), Russia (75 \%), Belgium (73\%) and China (70 \%) whereas in Sweden, Turkey, Romania, Greece and Finland most of the companies do not provide organizational incentives for their managers.

Table 1a: Country clusters according to level of performance the companies pay for

\begin{tabular}{|l|l|l|l|l|}
\hline & $\begin{array}{l}\text { Cluster } \\
\mathbf{1}\end{array}$ & Cluster 2 & $\begin{array}{l}\text { Cluster } \\
\mathbf{3}\end{array}$ & $\mathbf{p}$ (Anova test) \\
\hline $\begin{array}{l}\text { Cluster center } \\
\text { for individual } \\
\text { bonus }\end{array}$ & 0,76 & 0,59 & 0,38 & 0,000 \\
\hline $\begin{array}{l}\text { Cluster center } \\
\text { for team bonus }\end{array}$ & 0,54 & 0,32 & 0,22 & 0,000 \\
\hline $\begin{array}{l}\text { Cluster center } \\
\text { for } \\
\text { organizational } \\
\text { bonus }\end{array}$ & 0,73 & 0,46 & 0,39 & 0,000 \\
\hline Countries & $\begin{array}{l}\text { France } \\
\text { Italy } \\
\text { UK } \\
\text { Russia } \\
\text { Belgium } \\
\text { China }\end{array}$ & $\begin{array}{l}\text { Germany } \\
\text { Switzerland } \\
\text { Austria } \\
\text { Netherlands } \\
\text { Greece } \\
\text { Denmark } \\
\text { South } \\
\text { Africa } \\
\text { Croatia } \\
\text { USA } \\
\text { Turkey }\end{array}$ & $\begin{array}{l}\text { Australia } \\
\text { Brazil } \\
\text { Finland } \\
\text { Norway } \\
\text { Sweden } \\
\text { Romania }\end{array}$ & $\begin{array}{l}\text { The countries in different clusters } \\
\text { diverge } \\
\text { regarding pay for performance } \\
\text { systems' prevalence }\end{array}$ \\
& & & \\
\hline
\end{tabular}

In Table 1a, the countries have been grouped according to prevalence of managerial pay for performance. The companies in the countries in Cluster 1 most prevalently pay their managers for performance. In the countries in Cluster 2, pay for performance systems are moderately used. Finally, most of the companies in the countries in Cluster 3 do not pay their managers for performance. The results of the cluster analysis indicate that the countries in different clusters diverge in terms of pay for performance systems' prevalence. 
Secondly in the research, prevalence of long term incentives provided to managers in the 23 countries is examined. Here, prevalence of profit-sharing, stock options and employee share schemes as long term incentives which link compensation to firm performance is investigated. It is seen in Table 2 that profit-sharing is the main form of participation from among the incentives examined. Especially in France almost all companies $(89 \%)$ provide profit-sharing schemes to their managers. Most of the companies provide profit-sharing schemes to their managers as well in Brazil (57\%) and Germany (54\%). Almost half of the companies use profit-sharing schemes in countries such as Switzerland, China and Austria.

Previous research reveals that about $30 \%$ of the companies provided profit-sharing schemes to their employees in Europe in 2013 (Eurofound 2016: 107). France, as a country where profit-sharing was provided in the 1960's to promote participation in management and to reduce conflicts between employees and managers (Delahaie and Duhautois, 2019: 108), is distintly different from the other countries due to high prevalence of these plans. Specifically, $41 \%$ of the companies provide profit-sharing plans to their employees in France (Eurofound 2016: 107). Our results also reveal that France differs from the other countries with high scope $(89 \%)$ of profit-sharing schemes. The difference between the results of this research and previous research may derive from that we only focus on managers, while the previous research focused on all employees. It is expected that profit-sharing as a long term incentive would be provided to managers rather than all employees.

Comparing our results to Pendleton et al (2001) study based on Cranet data, it is seen that prevalence of profit-sharing plans provided to managers in France has reached 89 $\%$ now from $79 \%$ in 1992. However, there seems to be a decreasing trend in the use of profit-sharing in the other countries for instance the UK (from $36 \%$ to $28 \%$ ), the Netherlands (from $48 \%$ to $28 \%$ ), Austria (from $64 \%$ to $44 \%$ ) and Germany (from 68 $\%$ to $54 \%$ ) since 2000 .

Table 2 also indicates that employee share schemes are used by half of the participating companies in China. Managers in France are also provided employee share schemes in almost half (40\%) of the companies. The companies in the UK and 
Belgium follow France with $35 \%$ and $32 \%$ in the use of employee share schemes respectively. In contrast, employee share schemes are rarely provided as a whole in the rest of the countries examined. Examining the trend in the use of employee share schemes, Pendleton et al. (2001) study based on Cranet data provides us longitudinal data. Comparing our results to Pendleton et al. (2001) study, it is seen that there has been an increasing trend in France in the use of employee share schemes since 1992. In France, $14 \%$ of the companies provided stock options to their managers in 1992, the ratio has reached $39 \%$ in 2000 (Pendleton et al. 2001) and $40 \%$ in 2015 in our research. There seems to be a slow increasing trend in the use of employee share schemes in Belgium (from $30 \%$ in 2000 to $32 \%$ in 2016), Italy (15\% in 2000 to $21 \%$ in 2016) and Austria (9\% in 2000 to $11 \%$ in 2016) as well since 2000. However, the rate of companies providing employee share schemes to their managers is at the lowest level in countries such as the UK, the Netherlands, Germany, Denmark and Finland according to our research results. Specifically, the use of employee share schemes in the UK decreased from $45 \%$ in 2000 to $35 \%$ in 2016. A dramatic decrease is observed in the use of employee share schemes in the Netherlands with $43 \%$ in 2000 and $10 \%$ in 2016. The prevalence of employee share schemes decreased from $20 \%$ in 2000 to $10 \%$ in 2016 in Germany, from $22 \%$ to $12 \%$ in Denmark and finally $30 \%$ to $8 \%$ in Finland. Therefore, we can not conclude that there is a strict increasing or decreasing trend in the use of employee share schemes even though the European Working Conditions Survey results (2010) indicate that employee share ownership expanded by $1,9 \%$ (Agnes et al. 2012). 
Table 2: Long Term Incentives for Managers

\begin{tabular}{|c|c|c|c|c|c|c|}
\hline \multirow[t]{2}{*}{ Country } & \multicolumn{2}{|c|}{ Profit Sharing } & \multicolumn{2}{|c|}{$\begin{array}{l}\text { Employee } \\
\text { Schemes }\end{array}$} & \multicolumn{2}{|c|}{ Stock Options } \\
\hline & $(\%)$ & $(\mathbf{f} / \mathbf{N})$ & $(\%)$ & $(\mathbf{f} / \mathbf{N})$ & $(\%)$ & $(\mathbf{f} / \mathrm{N})$ \\
\hline France & 89 & $135 / 151$ & 40 & $59 / 146$ & 27 & $39 / 143$ \\
\hline Brazil & 57 & $200 / 354$ & 11 & $38 / 354$ & 12 & $41 / 354$ \\
\hline Germany & 54 & $144 / 269$ & 10 & $28 / 273$ & 16 & $43 / 269$ \\
\hline Switzerland & 46 & $86 / 186$ & 21 & $38 / 185$ & 23 & $42 / 182$ \\
\hline China & 45 & $114 / 256$ & 50 & $129 / 256$ & 31 & $79 / 256$ \\
\hline Austria & 44 & $94 / 213$ & 11 & $24 / 210$ & 16 & $33 / 213$ \\
\hline Belgium & 31 & $41 / 133$ & 32 & $43 / 134$ & 46 & $62 / 135$ \\
\hline Netherlands & 28 & $46 / 162$ & 10 & $17 / 163$ & 11 & $18 / 164$ \\
\hline Romania & 28 & $63 / 225$ & 1 & $2 / 225$ & 16 & $35 / 225$ \\
\hline UK & 28 & $28 / 100$ & 35 & $38 / 108$ & 26 & $26 / 99$ \\
\hline Russia & 25 & $32 / 128$ & 5 & $6 / 128$ & 8 & $10 / 127$ \\
\hline USA & 21 & $76 / 362$ & 18 & $64 / 362$ & 16 & $58 / 362$ \\
\hline Norway & 20 & $32 / 163$ & 19 & $31 / 163$ & 7 & $12 / 163$ \\
\hline Croatia & 18 & $27 / 153$ & 13 & $21 / 157$ & 17 & $26 / 156$ \\
\hline Turkey & 18 & $27 / 154$ & 15 & $23 / 154$ & 12 & $19 / 154$ \\
\hline Hungary & 13 & $34 / 273$ & 13 & $35 / 273$ & 9 & $24 / 273$ \\
\hline $\begin{array}{l}\text { South } \\
\text { Africa }\end{array}$ & 13 & $16 / 121$ & 17 & $21 / 121$ & 7 & $8 / 121$ \\
\hline Sweden & 13 & $33 / 261$ & 15 & $40 / 261$ & 8 & $21 / 261$ \\
\hline Denmark & 12 & $22 / 178$ & 12 & $21 / 178$ & 12 & $22 / 178$ \\
\hline Australia & 11 & $44 / 395$ & 16 & $64 / 395$ & 12 & $46 / 395$ \\
\hline Greece & 11 & $19 / 180$ & 23 & $41 / 180$ & 19 & $34 / 181$ \\
\hline Finland & 10 & $17 / 173$ & 8 & $14 / 180$ & 8 & $14 / 179$ \\
\hline Italy & 10 & $16 / 168$ & 21 & $36 / 168$ & 14 & $23 / 168$ \\
\hline
\end{tabular}

What is noteworthy regarding the use of stock options, almost half (46\%) of the participating companies in Belgium provide stock options to their managers. The prevalence of stock options in China is also quite high with $31 \%$. Except Belgium and China, stock options are rarely provided in the other countries. According to a research conducted in the US in 1999, of the 798 participating companies $49 \%$ provide stock options to their employees (Oyer and Scott, 2005: 106). Therefore, it is surprising to see that only $16 \%$ of the participating large companies provide stock options to their managers in this research.

Table $2 \mathrm{a}$ indicates country clusters regarding the prevalence of long term incentives. Firstly, the results support depending on each incentive's cluster center that profit- 
sharing is the most frequently used long term incentive. Moreover, countries in Cluster 1 statistically diverge from the countries in Cluster 2 in the use of profit-sharing schemes and stock options. Therefore, profit-sharing schemes and stock options are used in France, Belgium, Germany, Switzerland, Austria, China and Brazil more prevalently than in the countries in Cluster 2. On the other hand, the countries converge in the prevalence of employee share schemes examining the results of Anova test. As a result, employee share schemes are not used frequently as a whole. This finding is in line with the results of the European Company Survey 2013 indicating that employee share schemes are used by $5 \%$ of the European establishments (Eurofound, 2016).

Table 2a: Country clusters according to providing long term incentives

\begin{tabular}{|c|c|c|c|}
\hline & Cluster 1 & Cluster 2 & p (Anova test) \\
\hline $\begin{array}{l}\text { Cluster center for profit } \\
\text { sharing }\end{array}$ & 0,52 & 0,17 & 0,000 \\
\hline $\begin{array}{l}\text { Cluster center for stock } \\
\text { options }\end{array}$ & 0,26 & 0,13 & 0,002 \\
\hline $\begin{array}{l}\text { Cluster center for employee } \\
\text { share schemes }\end{array}$ & 0,25 & 0,15 & 0,055 \\
\hline Countries & $\begin{array}{l}\text { France } \\
\text { Belgium } \\
\text { Germany } \\
\text { Switzerland } \\
\text { Austria } \\
\text { China } \\
\text { Brazil }\end{array}$ & $\begin{array}{l}\text { Italy } \\
\text { UK } \\
\text { Russia } \\
\text { Netherlands } \\
\text { Greece } \\
\text { Denmark } \\
\text { South Africa } \\
\text { Croatia } \\
\text { USA } \\
\text { Turkey } \\
\text { Australia } \\
\text { Hungary } \\
\text { Finland } \\
\text { Norway } \\
\text { Sweden } \\
\text { Romania }\end{array}$ & $\begin{array}{l}\text { The countries in } \\
\text { different clusters } \\
\text { diverge in terms of } \\
\text { providing profits and } \\
\text { stock options, } \\
\text { whereas they } \\
\text { converge in terms of } \\
\text { providing employee } \\
\text { share schemes to } \\
\text { their managers. }\end{array}$ \\
\hline
\end{tabular}




\section{CONCLUSION}

This study aims to determine the current prevalence of managerial pay for performance systems in various countries. The results indicate in which countries the companies establish pay for performance systems to what extend and individual, team and organizational based pay for performance systems for managers are and are not prevalent. According to the findings, firstly paying for individual performance is still the biggest trend in many countries. Therefore, the results of this study are in line with the relevant literature (Long and Shields, 2005; Gerhart and Fang, 2014; Eurofound, 2016) indicating individual bonus is the most frequently used variable pay element provided to employees. On the other hand, for several countries such as the UK and China, paying for organizational performance is more prevalent than paying for individual performance.

Paying for individual performance is especially widespread in France (91\%), Italy (81 $\%)$, the UK (79 \%), Russia (76\%) and Belgium (73\%). In addition, companies heavily pay for organizational performance again in the UK (83\%), Italy (79\%), Russia (75\%), Belgium (73\%) and China (70 \%). Finally, paying for team performance is most prevalent in China (63\%), Italy (59\%), Russia (54\%) and Belgium (52\%). Regarding long term incentives, it is clearly seen that France is the country where profit-sharing is most prevalently used for managers with $89 \%$. Brazil and Germany follows France in this with $57 \%$ and $54 \%$ respectively. What is noteworthy regarding employee share schemes is that half of the companies in China provide employee share schemes to their managers. France follows China with $40 \%$ in this regard. Moreover, $35 \%$ of the companies in the UK use employee share schemes. According to our research results, Belgium is the country where stock options are most prevalently used. Specifically, nearly half of the companies (46\%) provide stock options to their managers in Belgium. Following Belgium, it is seen that one third of the companies in China use stock options. Except from the above-mentioned results, long term incentives are not used widespreadly in most of the countries. 
Our results support the findings of relevant studies (Pendleton et al. 2001; Guery et al. 2016) indicating that France has always been the country where financial participation is most prevalent. This can be partly explained by a legislative framework promoting financial participation in France (Floquet et al. 2016, s.281).

Finally, the results of this study indicating the current scene regarding the prevalence of pay for performance in various countries may be useful for global companies. Global companies need to know in which countries and how widely companies establish pay for individual, team and organizational performance systems. In other words, the findings of this research may help decision-makers of global companies who plan to perform in these countries in determining their compensation policies.

\section{REFERENCES}

Adeoye, A. O., \& Elegunde, A.F. (2014). Compensation Management and Motivation: Cooking Utensils for Organisational Performance. Mediterranean Journal of Social Sciences, 5(27), 88-97.

https://doi.org/10.5901/mjss.2014.v5n27p88

Agnès, P. T., Isabella, B., Jorge, C., Oscar, V. L., Greet, V., Aleksandra, W., \&Mathijn, W. (2012). Fifth European Working Conditions Survey-Overview Report.

Bloom, N.; \& Van Reenen, J. (2011). Human Resource Management and Productivity, In Handbook of Labor Economics, Amsterdam Elsevier NorthHolland, 1697-1767.

https://doi.org/10.1016/S0169-7218(11)02417-8

Booth, A.L., \& Frank, J. (1999). Earnings, Productivity and Performance-

Related Pay. Journal of Labor Economics, 17(3), 447-463. https://doi.org/10.1086/209927

Brewster, C., Mayrhofer, W., \& Reichel, A. (2011). Riding the Tiger? Going Along with Cranet for Two Decades-A Relational Perspective. Human Resource Management Review, 21(1), 5-15. https://doi.org/10.1016/j.hrmr.2010.09.007

Bryson A., Freeman R., Lucifora C., Pellizzari M., \& Perotin V. (2012). Paying 
for Performance: Incentive Pay Schemes and Employees' Financial Participation. CEP Discussion Paper No. 1112, The London School of Economics and Political Science.

Cadsby, C. B., Song, F., \& Tapon, F. (2007). Sorting and Incentive Effects of Pay for Performance: An Experimental Investigation. Academy of Management Journal, 50(2), 387-405.

https://doi.org/10.5465/amj.2007.24634448

Carson, T. L. (2003). Self-Interest and Business Ethics: Some Lessons of the Recent Corporate Scandals. Journal of Business Ethics, 43(4), 389-394. https://doi.org/10.1023/A:1023013128621

Cerasoli, C. P., Nicklin, J. M., \& Ford, M. T. (2014). Intrinsic Motivation and Extrinsic Incentives Jointly Predict Performance: A 40-Year Meta-Analysis. $\begin{array}{lll}\text { Psychological } \quad \text { Bulletin, } & \text { 140(4), }\end{array}$ https://doi.org/10.1037/a0035661

Chingos, P. T. (2002). Paying for Performance: A Guide to Compensation Management. John Wiley \& Sons.

DeCenzo, D. A., Robbins, S. P., \& Verhulst, S. L. (2013). Fundamentals of Human Resource Management. (11th ed.). NJ: John Wiley \& Sons, Inc.

Delahaie, N., \& Duhautois R. (2019). "Profit Sharing and Wages: An Empirical Analysis Using French Data between 2000 and 2007. British Journal of Industrial Relations, 57(1), 107-142.

https://doi.org/10.1111/bjir.12295

Delfgaauw, J., Dur, R., \& Souverijn, M. (2018). Team Incentives, Task Assignment, and Performance: A Field Experiment. The Leadership Quarterly. https://doi.org/10.1016/j.leaqua.2018.03.003

Dessler, G. (2016). Human Resource Management. 15th Ed., Pearson.

Durham C.C., \& Bartol, K.M. (2000). Pay for Performance. In E.A. Locke (Ed.)

Blackwell Handbook of Principles of Organizational Behavior, Oxford, UK:

Blackwell, 150-165.

Eurofound, (2016). Changes in Remuneration and Reward Systems. Publications Office of the European Union, Luxembourg. 
Gerhart, B., \& Fang, M. (2014). Pay for (Individual) Performance: Issues, Claims, Evidence and the Role of Sorting Effects. Human Resource Management Review, 24(1), 41-52.

https://doi.org/10.1016/j.hrmr.2013.08.010

Gielen, A.C., Kerkhofs, M.J.M., \& Von Ours, J.C., (2010). How Performance

Related Pay Affects Productivity and Employment. Journal of Population Economics, 23(1), 291-301.

https://doi.org/10.1007/s00148-009-0252-9

Gilbreath, B., \& Harris, M. M. (2002). Performance-Based Pay in the Workplace: Magic Potion or Malevolent Poison?. The Behavior Analyst Today, 3(3), 311-322.

https://doi.org/10.1037/h0099987

Gooderham, P., Fenton-O'Creevy, M., Croucher, R., \& Brookes, M. (2018). A Multilevel Analysis of the Use of Individual Pay-for-Performance Systems. Journal of Management, 44(4), 1479-1504. https://doi.org/10.1177/0149206315610634

Floquet, M., Guery, L., Laroche, P., \& Stévenot, A. (2016). Profit Sharing in France: Substitute or Complement to Wages. in Fietze, S. and Matiaske, W. (eds.), Dimensions and Perspectives of Financial Participation in Europe, Nomos Publishing, 241-262.

https://doi.org/10.5771/9783845259413-240

Hüttenbrink, A., Oehmichen, J., Rapp, M. S., \& Wolff, M. (2014). Pay-forPerformance-Does One Size Fit All? A Multi-Country Study of Europe and the United States. International Business Review, 23(6), 1179-1192. https://doi.org/10.1016/j.ibusrev.2014.04.002

James Jr, H. S. (2005). Why Did You Do That? An - Economic Examination of the Effect of Extrinsic Compensation on Intrinsic Motivation and Performance. Journal of Economic Psychology, 26(4), 549-566. https://doi.org/10.1016/j.joep.2004.11.002

Jenkins Jr, G. D., Mitra, A., Gupta, N., \& Shaw, J. D. (1998). Are Financial Incentives Related to Performance? A Meta-Analytic Review of Empirical 
Research. Journal of Applied Psychology, 83(5), 777-787. https://doi.org/10.1037/0021-9010.83.5.777

Kraizberg, E., Tziner, A., \& Weisberg, J. (2002). Employee Stock Options: Are They Indeed Superior to Other Incentive Compensation Schemes? Journal of Business and 16(3), 383-390. https://doi.org/10.1023/A:1012820923455

Kruse, D. (1993). Profit Sharing: Does it Make a Difference? The Productivity and Stability Effects of Employee Profit-Sharing Plans. Kalamazoo, MI: W.E. Upjohn Institute for Employment Research. https://doi.org/10.17848/9780585261614

Larkin, I., Pierce, L., \& Gino, F. (2012). The Psychological Costs of Pay-for-Performance: Implications for the Strategic Compensation of Employees. Strategic Management Journal, 33(10), 1194-1214. https://doi.org/10.1002/smj.1974

Long, R. J., \& Shields, J. L. (2005). Performance Pay in Canadian and Australian Firms: A Comparative -Study. The International Journal of Human Resource Management, 16(10), 1783-1811.

https://doi.org/10.1080/09585190500298370

Noe, R. A., Hollenbeck, J. R., Gerhart, B., \& Wright, P. M. (2017). Human

Resource Management: Gaining a Competitive Advantage. New York, NY:

McGraw-Hill Education.

Oyer, P., \& Schaefer S., (2005). Why Do Some Firms Give Stock Options to All Employees?: An Empirical Examination of Alternative Theories. Journal of Financial Economics, 76(1), 99-133. https://doi.org/10.1016/j.jfineco.2004.03.004

Pendleton, A., Poutsma, E., Ommeren J., \& Brewster, C. (2001). Employee Share Ownership and Profit-sharing in the European Union. European Foundation for the Improvement of Living and Working Conditions, Luxembourg.

Poutsma, E., Blasi, J.R., \& Kruse D.L. (2012). Employee Share Ownership and Profit Sharing in Different Institutional Contexts. The International Journal of 
Human Resource Management, 23(8), 1513-1518. https://doi.org/10.1080/09585192.2012.661994

Sadullah, Ö.Z., (2018). İnsan Kaynakları Yönetimine Giriş: İnsan Kaynakları Yönetiminin Tanımı, Önemi ve Çevresel Faktörler. In Özçelik, A.O. et al. İnsan Kaynakları Yönetimi, 8. Ed. Beta Basım, İstanbul. 